\title{
Why the Affection of Federalism for Human Rights Is Unrequited and How the Relationship Could Be Improved
}

\author{
Eva Maria Belser
}

Introduction: A Story of Unrequited Affection ${ }^{1}$

Autonomy and human rights are in an uneasy relationship. Proponents of federal power-sharing usually work on the assumption that territorial autonomy allows actors of different tiers of government to better respect and protect human rights. They are convinced that federalism backs constitutionalism, democracy and good governance and see autonomy rights not as a hindrance to the fulfilment of individual rights and freedoms but as a useful contribution to it. However, human rights organisations and advocates rarely respond positively to the advances made by federalists. As they associate collective autonomy with different human rights standards for citizens of the same state, proponents of human rights generally look sceptically at autonomy arrangements. The federal affection for human rights is thus unrequited. Federal scholars and international organisations promoting decentralisation and other forms of power-sharing - keep praising federalism as a mechanism able to increase the state's legitimacy and efficiency, as well as to strengthen its capacity to implement minority and human rights. Human rights experts - and international organisations mandated to support human rights implementation however, are immune to such seduction and advocate for uniform approaches. They insist on the obligation to respect and protect all human beings equally, irrespective of their group affiliation or territory of residence.

This chapter does not question the fact that unequal human rights standards within one country occur when a power-sharing regime is fully implemented. Federalism may in fact cause citizens of a country to be treated differently depending on which subnational and local jurisdiction is applicable to them. Such a situation prima facie clashes with the principle of equality and

1 I am very grateful to MLaw Simon Mazidi for his valuable help in the preparation and the editing of this text. 
the fundamental requirements of justice for which it stands. However, equality must be understood differently in federal states. The subnational and local units are not inescapably bound to treat their citizens equally to the citizens of other units; they are instead encouraged to improve on international and national standards applicable to all. The major claim of the chapter is thus that inequality, even in the sensitive field of human rights, is not a problem to overcome per se but a situation to handle within the framework of national and international human rights obligations.

The chapter first documents the rebuff of federal arrangements by the human rights community. The tendency of human rights bodies to blame and shame federalism for insufficient human rights implementation will be explored by looking at the recommendations the United Nations human rights treaty bodies ${ }^{2}$ have issued towards Switzerland and other federal states. I will then attempt to classify these recommendations into three different groups (section 2) and endeavour to identify some of the sources of tensions and reasons for mistrust between the potential partners (section 3). The chapter will then explore avenues for improving the relationship between federalism and human rights and the respective communities. It will first recall the fact that some human rights obligations require the respect of collective rights and oblige state actors to accept and promote diversity (section 4). It will then more generally turn to multilevel human rights implementation and to the assets federalism and other forms of autonomy have to offer and suggest that the complexities of the relationship between autonomy and human rights are underexplored and many crucial questions have yet to be answered convincingly. While it is easy to conclude that we can and must accept unequal human rights standards in federal states, the question of how far inequality can go remains open. By using various examples, the chapter will show that the conventional answer - all actors must respect minimal standard and may improve on them - is not satisfactory (section 5). Finally, the chapter will, therefore, hint at avenues for further research (section 6).

\section{The Rejection of Federalism by Human Rights Treaty Bodies}

The Swiss Centre of Expertise in Human Rights (SCHR), a pilot project of the federal government in view of the establishment of an independent national

2 Cf. for a comprehensive study of the UN human rights treaty bodies, Helen Keller and Geir Ulfstein, UN Human Rights Treaty Bodies: Law and Legitimacy (Cambridge: Cambridge Univ. Press, 2012). 
human rights institution, recently analysed the recommendations the United Nations and the Council of Europe had made regarding human rights implementation and implementation deficits in Switzerland during the last years. ${ }^{3}$ The comprehensive study, published in six volumes, gives a detailed overview of the evaluation of Swiss human rights efforts and shortcomings by international human rights organisations and their implementation bodies.

When reacting to Switzerland's country and shadow reports, international bodies quite reliably welcome the adaption of new national laws, the establishment or strengthening of national institutions and the making and implementation of national action plans, e.g. the National Strategy to Combat Poverty or the National Action Plan to Fight Human Trafficking. ${ }^{4}$ When the country does not report on new federal initiatives but refers to cantonal and municipal competences, international bodies usually frown and call for more national action. $^{5}$

The very numerous recommendations referring to vertical power-sharing can be classified into three categories:

- In the first category, federalism-blind recommendations, we find comments and advice reminding Switzerland of its duty to implement human rights obligations throughout the country, irrespective of its internal organisation. Countless recommendations repeat that international treaties are binding on the entire country and that cantonal and municipal competences cannot serve as excuses for implementation deficits.

- The recommendations of the second category, federalism-adverse recommendations, refer to federalism as a particular challenge for human rights implementation and suggest that Switzerland harmonises its efforts, in particular by establishing national action plans, providing blueprints and frameworks for actors of all tiers, setting national priorities, coordinating and harmonising actions, and tracking progress nationally.

- In the third category, finally, we find federalism-hostile recommendations. These recommendations refer to federalism as a serious problem for human rights implementation and openly criticise subnational competences.

3 Schweizerischen Kompetenzzentrums für Menschenrechte, Umsetzung der Menschenrechte in der Schweiz, Schriftenreihe SKM R (Bern: Editions Weblaw, 2013-2014).

4 Cf. e.g., Human Rights Committee, Concluding Observations on the Fourth Periodic Report of Switzerland, CCPR/C/CHE/CO/4 (2017), para. 3 or Committee on the Elimination of Discrimination against Women, Concluding Observations on the Combined Fourth and Fifth Periodic Reports of Switzerland: CEDAW/C/CHE/CO/4-5 (2016), para. 5 .

5 Judith Wyttenbach, Umsetzung von Menschenrechtsübereinkommen in Bundesstaaten: Gleichzeitig ein Beitrag zur grundrechtlichen Ordnung im Föderalismus (Baden-Baden, Zürich, St. Gallen: Nomos Dike, 2017), 148. 
Federalism-hostile recommendations demand unified and unifying actions, for instance, by the adoption of a national law or other uniform rules or by national actions eliminating different human rights standards in the country.

The three categories of recommendations affect federalism and human rights in very different ways. While the first group states a matter of course, the second and the third groups question the conduciveness of federalism to human rights implementation.

\subsection{Federalism-Blind Recommendations}

Federalism-blind recommendations are very frequently issued when evaluating Switzerland and other federations. ${ }^{6}$ Typical recommendations summon Switzerland to 'ensure that the authorities in all cantons and municipalities are aware of the Committee's recommendations and guarantee their proper implementation ${ }^{7}$ or 'to work to promote equal representation of women in political life at all levels. ${ }^{8}$ In rare cases, international treaty bodies express concern about the situation in one or more cantons, e.g. regarding the overcrowding of prisons in the Canton of Geneva or the detention of unaccompanied minors unseparated from adults in some cantonal institutions. ${ }^{9}$

Federalism-blind human rights recommendations are unproblematic from both a federal and an international human rights viewpoint. From a federal perspective, it is uncontroversial that autonomy arrangements allow for diversity only within the binding framework of superior law. ${ }^{10}$ Vertical powersharing between actors of different government tiers constitutes no blank check to violate the country's international obligations. Subnational units are obliged to use their competences in the field of culture, education, religion, health or economic development in a way that does not fall behind any of

6 Committee on the Elimination of Discrimination against Women, Concluding Observations of the Committee on the Elimination of Discrimination Against Women: Canada, CEDAW/ C/CAN/CO/7 (2008), para. 11; Committee on the Elimination of Discrimination against Women, Concluding Observations on the Combined Eighth and Ninth Periodic Reports of Canada, CEDAW/C/CAN/CO/8-9 (2016), para. 11; Committee on the Elimination of Discrimination against Women, Concluding Observations of the Committee on the Elimination of Discrimination Against Women: Belgium, CEDAW/C/BEL/Co/6 (2008), para. 12; see for a further assessment on the unequal implementation of the UN Conventions rights in a federal state Wyttenbach, Umsetzung von Menschenrechtsübereinkommen in Bundesstaaten, 135 et seqq.

$7 \quad \mathrm{CCPR}$, Concluding Observations, /C/CHE/CO/4 (2017), para. 9.

8 CCPR, Concluding Observations, /C/CHE/CO/4 (2017), para. 19.

9 Committee against Torture, Concluding Observations on the Seventh Periodic Report of Switzerland, CAT/C/CHE/CO/7 (2015), para. 17 and 19. 
the national or international, justiciable or programmatic, human rights obligations. Diversity, as protected by the constitution, is contained by unity, as defined namely by international and constitutional human rights. Exclusive, concurrent or parallel competences of subnational units are limited by overriding international and national law and all subnational law must give in in case of conflict.1

From an international human rights perspective, federalism-blind human rights recommendations are equally self-evident. Under the notion of 'pacta sunt servanda' the Vienna Convention on the Law of Treaties famously states that every treaty in force is binding upon the parties to it and must be performed by them in good faith. ${ }^{12}$ The Convention adds that 'a party may not invoke the provisions of its internal law as justification for its failure to perform a treaty.'13 The unitary, decentral, regional or federal character of a state party has no impact on the country's international obligations and is rightly of little or no concern to international organisations and treaty bodies. ${ }^{14}$ The country as such is responsible for treaty implementation, irrespective of its internal power-sharing arrangement. ${ }^{15}$

Federalism is thus obviously no excuse to fall behind on international human rights obligations. While internally, the federal tier may find it difficult to ensure full and speedy compliance with international duties because it lacks (comprehensive) competences, externally such difficulties are irrelevant. ${ }^{16}$ If one canton or municipality disrespects human rights, the state falls short of its international obligations. All multi-tier states must hence find mechanisms to apply international and national laws to the entire territory and enforce their primacy over all conflicting subnational laws and acts. If a state is unwilling or

11 Francesco Palermo and Karl Kössler, Comparative Federalism: Constitutional Arrangements and Case Law (Portland, Oregon: Hart Publishing, 2017), 130 et seqq.

12 Art. 26 of the Vienna Convention on the Law of Treaties.

13 Art. 27 of the Vienna Convention on the Law of Treaties; see Committee on Economic, Social and Cultural Rights, General Comment No. 9: The Domestic Application of the Covenant, E/C.12/1998/24 (1998).

14 Committee against Torture, Consideration of Reports Submitted by States Parties Under Article 19 of the Convention: Concluding Observations of the Committee Against Torture, Switzerland, СAT/C/CHE/CO/6 (2O10), para. 6 .

15 Florian Weber, "Die Umsetzung völkerrechtlicher Verträge im Bundesstaat," in Föderalismus 2.o - Denkanstösse und Ausblicke, eds. Bernhard Waldmann, Peter Hänni and Eva Maria Belser (Bern: Stämpfli, 2011), 222.

16 Christoph Spenlé and Jan Skalski, "Das Staatenberichtsverfahren vor dem UNO-Ausschuss gegen die Diskriminierung der Frau: Das unterschätzte Instrument: Zur Funktion und Struktur der UNO-Staatenberichtsverfahren und ihrer Bedeutung für die Schweiz," Jusletter, 31 Ocober 2011, No. 51 . 
unsuccessful in using these mechanisms, international bodies rightly insist on the respect and protection of human rights by all state actors, be they federal, cantonal or municipal.

\subsection{Federalism-Adverse Recommendations}

Federalism-adverse recommendations refer to federalism and other autonomy arrangements as particular challenges for the proper implementation of human rights. The Human Rights Committee, for example, stated that it 'takes note of the federal structure of the Swiss State and the division of powers between the authorities at the federal, cantonal and municipal levels. It remains concerned, however, about information suggesting that the commitment on the part of the cantonal and municipal authorities to the implementation of its recommendations is limited. ${ }^{17}$ In order to make up for the situation, the Committees usually suggest that the federal tier should interfere and recommend strengthening national actors or adopting national action plans. The Human Rights Committee, for instance, invited Switzerland to 'redouble its efforts to combat the commission of or incitement to commit acts of racial or religious hatred, notably by strengthening the mandate of the Federal Commission against Racism and by envisaging the adoption of a national plan of action against racism.'. ${ }^{18}$ In the same report, it also suggested that in order to better protect persons leading a nomadic way of life, Switzerland 'should establish with the cantons a coordinated action plan to ensure that sufficient stopping areas are made available to Travellers.' ${ }^{19}$ Similarly, the Committee on Economic, Social and Cultural Rights called for the adoption of a 'national action plan for the prevention of suicide. ${ }^{20}$ In addition to such a specific measure, the harmonisation of human rights measures at federal level is frequently proposed. The country should, for instance, 'establish expeditiously' universal and independent mechanisms with powers to receive all complaints concerning police violence and to maintain centralised statistics. ${ }^{21}$ Similarly, the Committee on Economic, Social and Cultural Rights encouraged Switzerland to promote the harmonisation of standards for access to preschool and childcare, 'so as to

17 CCPR, Concluding Observations, /C/C HE/CO/4 (2017), para. 8.

18 CCPR, Concluding Observations, /C/CHE/CO/4 (2017), para. 21.

19 CCPR, Concluding Observations, /C/C HE/CO/4 (2017), para. 51.

20 Committee on Economic, Social and Cultural Rights, Consideration of Reports Submitted by States Parties Under Articles 16 and 17 of the Covenant: Concluding Observations of the Committee on Economic, Social and Cultural Rights, Switzerland, E/C.12/CHE/CO/2-3 (2010), para. 19. CCPR, Concluding Observations, /C/CHE/CO/4 (2017), para. 29. 
ensure that all children living in the territory of the State party have the same opportunities to benefit'.22 It also asked to set 'common standards for access and entitlement to social aid.' ${ }^{23}$

Federalism-adverse recommendations, calling for targeted national interventions or comprehensive national strategies and frameworks, ${ }^{24}$ are questionable from a federal point of view. They often recommend measures, which the national constitution does not allow the federal tier to take. Such international invitations to disrespect entrenched national power-sharing arrangements are problematic. If one or several subnational units use their internal competences in a way which is incompatible with the country's international obligations, the state party is undoubtedly bound to remedy the situation. The means used to do so, however, are up to the state to identify. States should not make their best efforts to fully implement international human rights at the price of constitutionalism and the rule of law, but must ensure implementation methods which are constitutional and, in federal systems, respectful of autonomy rights. Federal governments are equipped with mechanisms, such as judicial review, supervisory and intervention powers, allowing them to impose the supremacy of international over subnational law and practice. Therefore, when a subnational unit violates international human rights, the application of these mechanisms to enforce the relevant right in that unit should be the first consequence. While international bodies tend to see even unconstitutional unification and harmonisation as the only way forward, federal state parties should rather be summoned to use their constitutional powers to bring subnational outliers in line. Such targeted interventions are often more effective than the adaption of national plans and frameworks, which tend to codify a national minimum and, in the absence of implementation mechanisms, run the risk of being disrespected by the very same subnational actors violating international obligations in the first place. Hence the real issue at stake is the proper design and use of supervisory and intervention powers to deal with human rights violations, wherever they may occur. Often, the increase of information and human rights awareness, the strengthening of the judicial system

\footnotetext{
22 CESCR, Concluding Observations, E/C.12/CHE/CO/2-3 (2010), para. 22.

23 CESCR, Concluding Observations, E/C.12/CHE/CO/2-3 (2O10), para. 12.

24 CESCR, Concluding Observations, E/C.12/CHE/CO/2-3 (2O10), para. 19; CCPR, Concluding Observations, /C/CHE/CO/4 (2017), para. 41; Committee on the Rights of the Child, Concluding Observations on the Combined Second to Fourth Periodic Reports of Switzerland, CRC/C/CHE/CO/2-4 (2015), para 9, 11, and 13; Committee on the Elimination of Discrimination of Discrimination against Women, Concluding Observations of the Committee on the Elimination of Discrimination Against Women: Switzerland, CEDAW/C/ $\mathrm{CHE} / \mathrm{CO} / 3$ (2OO9), para. 20 and 22.
} 
and initiatives to improve access to courts, in particular for vulnerable persons, are the most promising ways forward, rather than the national proliferation of human rights commitments. ${ }^{25}$

Federalism-adverse recommendations are debatable from a human rights perspective, too. They implicitly start from the assumption that unified and harmonised human rights standards will automatically guarantee better human rights implementation. This assumption is, however, erroneous as will be further demonstrated below. Uniform standards can just as well lead to a minimal national agreement and prevent progressive units from excelling. Instead of forcing all federal actors to uniform standards, it appears as more promising to oblige actors who are not fulfilling their duties to improve. ${ }^{26}$

\subsection{Federalism-Hostile Recommendations}

Federalism-hostile recommendations refer to federalism as an obstacle to human rights implementation and criticise subnational competences and the inequalities resulting from them. They suggest the limitation or suppression of subnational autonomy and the adoption of uniform actions. The aim of federalism-hostile recommendations is to eliminate different human rights standards in a country, irrespective of the country's internal organisation. Federalism-hostile recommendations, for instance, express serious concerns about 'the fact that the cantons lack a common procedure'27 and ask Switzerland 'to see to it that the cantons establish a uniform and coordinated procedure for identifying trafficking victims. ${ }^{28}$ The Committee also recommends 'that the State party considers adopting a comprehensive antidiscrimination law enforced uniformly throughout the confederation.' ${ }^{29}$ Regarding the implementation of the UN Covenant on economic, social and cultural rights, the Committee recommends that Switzerland 'take steps to agree upon comprehensive legislation giving effect to all economic, social and cultural rights uniformly between the federal Government and the cantons'. It also encourages the country 'to pursue its efforts of harmonizing cantonal laws

25 Cf. Solomon Ebobrah and Felix Eboibi, "Federalism and the Challenge of Applying International Human Rights Law Against Child Marriage in Africa," Journal of African Law 61, no. 3 (2017).

26 Eva Maria Belser, "Kantonale Grundrechte und ihre Bedeutung für die Verwirklichung der Menschenrechte im mehrstufigen Staat," in Die Europäische Menschenrechtskonvention und die Kantone, eds. Samantha Besson and Eva Maria Belser (Geneva, Zurich, Basel: Schulthess 2014), 81 et seq.

27 CCPR, Concluding Observations, /C/CHE/CO/4 (2017), para. 40.

28 CCPR, Concluding Observations, /C/CHE/CO/4 (2017), para. 41.

29 CESCR, Concluding Observations, E/C.12/CHE/CO/2-3 (2010), para. 7 . 
and practices to ensure equal enjoyment of Covenant rights throughout the confederation' ${ }^{30}$

Federalism-adverse recommendations are problematic from a federal, constitutional and a human rights point of view. They encourage states to disrespect their own constitutions and the power-sharing regime that they have established. By imposing uniform solutions, they also forego the opportunity of creating a competitive atmosphere of progressive human rights improvement within the state and run the risk of impairing efficient and comprehensive human rights implementation by the joined forces of all tiers of government. The above-mentioned danger that national bodies settle on minimum standards and race these standards to the bottom, and not to the top, is real. Just as it is easier for individual states to agree on higher standards than what has been achieved between the very diverse international actors in global arenas, it is more likely for small and often more homogenous subnational units and local entities, such as cities, to strive for human rights standards that exceed the international minimum than for country as a whole. The more diverse the actors sitting around the decision-making table are, the more likely it is that they settle on a minimal agreement. Once uniform solutions have been established, they hinder regional and local innovation in human rights and prevent state actors - who are closest to the people, their needs and priorities - to experiment with new rights and freedoms as well as innovative implementation instruments. Comprehensive national legislation typically leaves either no legal space or no incentive for subnational units and local governments to improve standards above nationwide and international consensus.

\section{Some Causes for the Unhappy Relationship}

The UN treaty bodies' practice concerning Switzerland shows a rather sceptical approach to the federal system of the country. Federalism-adverse or federalism-hostile recommendations issued by the UN treaty bodies hint at the fact that from an international law perspective, federalism and multilevel governance are perceived as preventing the effective implementation of international human rights obligations. Before recalling to what extent numerous overlaps between federalism and human rights exist and reiterating the opportunities offered by multilevel human rights implementation, I will try to explore some of the reasons for the unhappy relationship. Why indeed does 
the federal affection for human rights, despite the theoretical and often very practical advantages power-sharing has to offer, remain unrequited? What are the reasons for the international human rights community showing such a high level of mistrust towards power-sharing arrangements and cantonal and municipal competencies? As in most unhappy relationships, the reasons are manifold and linked to the different backgrounds and upbringings of the partners, the negative experiences the companions have had in the past and expect for the future, and the lack of open and regular communication that would help to overcome misunderstandings and bridge differences.

\subsection{The Different Backgrounds of the Partners}

One source of misunderstanding concerns the different approaches federal and human rights communities apply towards human rights implementation. While proponents of power-sharing arrangements tend to look at regionally and locally found and owned solutions and show a preference for bottom-up approaches to human rights implementation, advocates of human rights start from universal standards and are inclined towards top-down improvements.

The different approaches can be seen as part of the more general controversies about the universality or cultural relativity of human rights, but very often have just as much to do with the different trajectories and career paths of the respective actors. Experts of federalism, on the one hand, are often overwhelmed by the complexities of internal power-sharing and by the intricacies of establishing counter-majoritarian mechanisms entrenching autonomy for smaller and vulnerable groups; their focus lies on the protection and promotion of internal diversity, sometimes to the neglect of international law. Experts of human rights, on the other hand, frequently emphasise international obligations and show limited interest in domestic law. The respective neglect of other disciplines often has its source in different training paths and the separation of international and constitutional law at universities and in research. Experts in both communities have various educational backgrounds and often lack sensitivity and sometimes knowledge about the concepts and rules of the other field. There are presumably few federal scholars thoroughly following their countries' international obligations and the concerns of international treaty bodies, and there are probably even fewer human rights actors examining domestic constitutions beyond the human rights catalogue. While federalists work nationally and subnationally, human rights experts are active on the national and international level. The former are part of internal power struggles, the latter cooperate globally. The human rights community, linked with powerful international human rights organisation, are active in submitting shadow reports and presumably have a crucial impact on international 
recommendations; the federalism community does not have similar networks and does not generally take part in the reporting and follow-up processes of human rights treaties. Overall, the two communities rarely meet.

\subsection{Negative Experiences}

Another source of mistrust between proponents of federalism and human rights stems from past and current experiences with bottom-up and top-down approaches to human rights. In the past and present, subnational actors have attempted to refer to self-rule as a justification for not respecting and protecting the rights and freedoms of all their citizens. ${ }^{31}$ Famously, the southern states of the USA did not implement equal rights for black citizens until constitutional amendments, decisions of the Federal Supreme Court and the deployment of the National Guard forced them to do so. ${ }^{32}$ Notoriously, the Swiss canton of Appenzell Innerrhoden refused to accept women's voting rights until it was obliged to do so by a judgement of the Federal Supreme Court in 199o. ${ }^{33}$ Such experiences seem to teach us that national authorities are the only reliable guarantor of universal human rights.

This is especially true for new and fragile federations introducing federalism to overcome internal conflicts and deal with legacies of marginalisation and oppression. Federalism is often planted in conflict-ridden ground where trust between groups and regions is lacking. In such a fragile context, subnational autonomy can be perceived as a proxy to regional nationalism, or as a blank cheque for power abuse. It thus does not come as a surprise that in states negotiating or implementing federal systems, fears of human rights violations by subnational actors often loom. Will subnational actors organise themselves democratically or be captured by regional elites? Will they turn against minorities within minorities and serve smaller groups (including members of the majority groups residing on their territory) with the treatment they are escaping from? Will traditional groups use self-rule to break free from more liberal or progressive national rules and policies? Will the self-determination of groups come at the price of gender equality and LGBT rights?

Such fears, as justified as they might be in a specific context, disregard the fact that international and national human rights are binding on all state actors on all tiers of government. It is a characteristic of federal systems that

$31 \quad$ Nico Steytler, "The Constitutional Conversation Between the Federal Structure and a Bill of Rights," IFF Working Paper Online No. 2, 7.

32 Oliver Brown, et al. v. Board of Education of Topeka, et al., 347 U.S. 483 (1954).

33 Decision of the Swiss Federal Court, BGE 116 Ia 359; Eva Maria Belser, "Kantonale Grundrechte", 77 et seqq. 
international and national law, most importantly human rights, take precedence over conflicting subnational laws and decisions. Federalism thus does not come with an inherent risk of human rights violations. Federal diversity unfolds in unity, and ends where overriding values, in particular human rights, are at stake. In no federal system does regional and local autonomy include the possibility of autonomous actors to opt out of binding international human rights obligations. It is rather a characteristic of federations that national constitutions, including their human rights catalogue, are enforced by neutral umpires, supreme or constitutional courts, and that all laws and decisions violating the constitution - whether of national, subnational or local origin - are invalid. ${ }^{34}$ Hence, the real concern is an overall legal and political commitment to human rights, constitutionalism and an independent judiciary - often lacking in federal as well as unitary states.

It is true that human rights violations often occur in conflict-prone and fragile states characterised by deep inequalities between groups and regions. This risk, however, exists independently from the state's internal organisation and must be mitigated by giving priority to human rights implementation. If national actors (and international actors such as donors) fail to do so, human rights violations will persist in some or all regions of the state no matter whether vertical power sharing has been put in place or not. Blaming federalism for human rights violations thus is often like kicking the dog instead of its master. The tremendous discrepancies between international norms on the one hand, and local realities on the other, should rather be tackled for what they are: enforcement gaps. It is hard to see how these could be overcome without strengthening (instead of weakening) local institutions for the protection of human rights. ${ }^{35}$

\subsection{The Lack of Communication}

Another source of difficulty seems to come from the lack of appropriate communication between the international human rights bodies and federal states. Even in the national sphere, conversations between federalism and human rights are slow to develop. In research and practice, the two communities perceive themselves as foes rather than friends. The human rights focus

34 Ronald L. Watts, Comparing Federal Systems, 3rd ed. (Montreal and Kingston: McGillQueen's University Press, 2008), 157 et seqq.; Palermo and Kössler, Comparative Federalism, 130 et seqq.

35 See Axel Marx et al., Multilevel Protection of the Rule of Law and Fundamental Rights: The Role of Local and Regional Authorities and of the Committee of the Regions (European Union, 2014), 9 et seqq. 
usually lies on the tensions created by guarantees seeking to protect universal human rights norms and subnational autonomy, creating an obstacle to such an aim. ${ }^{36}$ In contrast, the federal approach aims at a balanced combination of self-rule and shared rule and tends to perceive sweeping universal standards as a potential threat to diversity. ${ }^{37}$ By guaranteeing rights and freedoms for all and empowering international treaty bodies and national authorities to monitor their implementation, human rights obligations are seen as mechanisms transferring decision-making powers to national and international actors and allowing them to develop and consolidate single standards applicable throughout the country. ${ }^{38}$

Canadian history is particularly telling in this regard. When the Canadian Bill of Rights was enacted in 1960 as an ordinary law, it was made applicable only to federal laws and did not cover provincial violations of civil liberties. It was only in 1982 that the Charter of Rights became part of Canadian constitutional law and applicable to federal as well as provincial acts of government. Ever since 'the Charter Revolution', ${ }^{39}$ human rights are said to have a centralising effect on Canadian federalism. As in other federations, the constitutional human rights guarantees do not confer any additional powers on the federal tier but limit the powers of both federal and provincial governments. By setting a uniform national standard for the protection of civil liberties in formerly exclusive provincial jurisdictions, its centralising effect is subtler than other centralising efforts. The Charter is a unifying instrument as it intrudes into provincial competences by nationalising debates on controversial matters such as school prayers, the funding of denominational schools, Sunday closing and other religious rights, minority language education and other linguistic rights, the right to strike, police powers, pornography and hate speech, abortion, and same-sex marriage. Irrespective of the federal power-sharing arrangements and provincial competences, the Supreme Court of Canada - like other

36 See for historic debates in Canada and the United States Jamie Cameron, "Federalism, Treaties, and International Human Rights Under the Canadian Constitution," Wayne Law Review 48, no.1 (2002), 1 et seqq.; Koren L. Bell, "From Laggard to Leader: Canadian Lessons on a Role for U.S. States in Making and Implementing Human Rights Treaties," Yale Human Rights and Development Law Journal 5, no. 1 (2002), 255 et seqq.

37 Steytler, "The Constitutional Conversation Between the Federal Structure and a Bill of Rights", 3; cf. also Wyttenbach, Umsetzung von Menschenrechtsübereinkommen in Bundesstaaten, 251.

38 Céline Fercot, "Perspectives on Federalism: Diversity of Constitutional Rights in Federal Systems," European Constitutional Law Review 4, no. 2 (2008), 320.

39 Frederick L. Morton and Rainer Knopff, The Charter Revolution and the Court Party (Peterborough: Broadview Press, 200o). 
Federal or Supreme Courts - has the final say in all matters involving chartered rights. ${ }^{40}$

Most federal scholars assume that national human rights actors such as constitutional or supreme federal courts have shown as little consideration for autonomy rights as international treaty bodies. The history of most established federations, they claim, tells stories of shrinking subnational policy space due to nationalised and international rights and freedoms. ${ }^{41}$ In most countries, subnational actors continuously see their room for manoeuvre limited by national developments, which are not infrequently triggered by international recommendations and international soft law. Regional and local authorities often feel that their constitutional competences in the field of education, health and social assistance give way to uniform service delivery standards established to strengthen equal citizenship at the expense of autonomy. ${ }^{42}$ In contrast, national human rights actors often see federalism as nothing else than a burden of history that should best be overcome and replaced by efficient and uniform human rights strategies.

The fact that advocates of federalism fear the centralising effect of human rights and courts which enforce them, and that national and international human rights bodies are unimpressed by vertical power-sharing and unwilling to respond to references to autonomy rights is caused, at least in part, by a lack of communication. The different focal points of human rights and federalism generate misunderstandings often making necessary dialogues inert. Some of the early reports of Switzerland to human rights treaty bodies, for instance, were full of gaps and voids when the country reported on the implementation of human rights by cantons and municipalities. While the reports gave detailed account of national measures in the fields of federal competences, they limited themselves to passing references to cantonal and municipal competences in

40 See Peter W. Hogg, "Federalism Fights the Charter of Rights," in Federal and Political Community: Essays in Honour of Donald Smiley, eds. David P. Shugarman and Reginald Whitaker (Peterborough: Broadview Press, 1989), 249 et seqq.

41 Cf. for the United States John Kincaid, "Values and Value Tradeoffs in Federalism," in Federalism: Volume 1: Historical and Theoretical Foundations of Federalism, ed. John Kincaid, Sage library of political science (Los Angeles: SAGE, 2011), 251 and William J. Brennan, JR., "The Bill of Rights and the States: The Revival of State Constitutions as Guardians of Individual Rights," New York University Law Review 61, no. 4 (1986), 540 et seqq.; cf. for Canada Roger Gibbins, Rainer Knopff, and Frederick L. Morton, "Canadian Federalism, the Charter of Rights, and the 1984 Election," Publius: The Journal of Federalism 15, no. 3 (1985); cf. for South Africa Steytler, "The Constitutional Conversation Between the Federal Structure and a Bill of Rights".

42 Steytler, "The Constitutional Conversation Between the Federal Structure and a Bill of Rights", 10 and 16. 
all others. When reacting to international human rights recommendations (on matters relating to education, health or policing), some official documents of the federal government would limit themselves to pointing to cantonal competences, basically requesting that the treaty bodies not blame the national drafters of the report for the shortcomings of other actors over which they do not exercise any influence. Even today, numerous country reports are very extensive and even loquacious when it comes to presenting national initiatives taken and federal laws made and, conversely, sketchy or silent when it comes to subnational activities. Unfortunately, insufficient efforts are being made to comprehensively document human rights improvements and innovations made by cantons and municipalities, even though these could be inspirational for international bodies, feed into reports and recommendations, and create multilevel and transnational feedback and learning loops.

In our analysis for the Swiss Centre of Expertise in Human Rights, we studied the mechanisms used in Switzerland to react to international human rights recommendations and to organise follow-up procedures, and were obliged to recognise that the relations between the federal and cantonal tier were full of tensions in the field. To prepare the very numerous country reports, different federal actors would send questionnaires to various cantonal actors, often requiring considerable amounts of data, documents and information, sometimes on short notice and sometimes asking for completion of forms, classifications and categories, which the cantons (or the municipalities) were not able to provide. ${ }^{43}$ Consequently, a vicious circle developed. Cantons did not report to the federal government or only handed in rather summary information. Therefore, the reports made by Switzerland documented only very partially the numerous cantonal initiatives in human rights fields. This led to the international treaty bodies issuing federalism-adverse or -hostile recommendations which, when forwarded to the cantons, further alienated them from the international human rights mechanisms. As complying to manifold international reporting duties and implementing numerous recommendations constitutes a real challenge for multilevel systems with multiple power centres, we presume that the difficulties we documented are not unique to Switzerland. ${ }^{44}$

43 Schweizerisches Kompetenzzentrum für Menschenrechte, Die Umsetzung internationaler Menschenrechtsempfehlungen im föderalistischen Staat: Perspektiven für das Followup zu den "Abschliessenden Bemerkungen" der UNO-Vertragsorgane in der Schweiz (Bern, 2012), 22 et seq.

44 See e.g. Human Rights Council, Report of the Special Rapporteur on Adequate Housing as a Component of the Right to an Adequate Standard of Living, and on the Right to Nondiscrimination in This Context, Leilani Farha: A/HRC/28/62 (2014), para. 5, 6 and 27. 
While some improvements have been made and coordinating bodies set up, it seems obvious that the reporting systems within federal countries must be further developed in order to produce productive feedback loops. There is an urgent need to establish and strengthen mechanisms to document local human rights initiatives properly and to feed this information into international review mechanisms. Such multilevel reporting will improve the understanding between federal and uniform approaches to human rights and inform international actors about human rights successes, difficulties and failures on the ground, a necessity for international learning from each other. ${ }^{45}$

Avenues for Advances

At first sight, it seems like there are structural limits regarding the compatibility of human rights and federalism as both are trying to promote different agendas. ${ }^{46}$ While international human rights bodies are dedicated to protecting and promoting universal human rights norms, the federal spirit embodies a desire to enhance subnational autonomy ${ }^{47}$ At second glance, however, numerous commonalities and chances for cooperation appear.

First, human rights and federalism aim at compatible and mutually reinforcing objectives. Both intend to improve governance and to protect diversity. Insofar as federal arrangements constrain power by establishing vertical checks and balances, they contribute to preventing power abuses and thus, similar to human rights, serve to limit state power and to strengthen rights and freedoms. ${ }^{48}$ Constrained power is more likely to respect and protect human rights - in particular, civil and political rights - than uncontrolled power.

Second, in states characterised by ethnic, religious or linguistic diversity, sharing power between groups and regions can be a requirement of international law. To recommend limiting or abandoning federal systems in such

45 Eva Maria Belser and Simon Mazidi, "Das Zusammenwirken von Bund und Kantonen bei der Einhaltung völkerrechtlicher Menschenrechtsverpflichtungen der Schweiz," in Jahrbuch des Föderalismus 2018: Föderalismus, Subsidiarität und Regionen in Europa, ed. Europäisches Zentrum für Föderalismus-Forschung Tübingen (EZFF) 19 (BadenBaden: Nomos, 2018), 257.

46 Cf. Wyttenbach, Umsetzung von Menschenrechtsübereinkommen in Bundesstaaten, 250 et seq.

47 Steytler, "The Constitutional Conversation Between the Federal Structure and a Bill of Rights", 3; cf. also Kincaid, "Values and Value Tradeoffs in Federalism", who draws a similar line between individual and communitarian liberty, 250. Wyttenbach, Umsetzung von Menschenrechtsübereinkommen in Bundesstaaten, 250. 
a context, therefore, makes no sense, either from a federal or from a human rights perspective. Given the generally negative approach of international human rights bodies towards federalism and the various reasons for misunderstandings and distrust, it seems appropriate to recall that the full implementation of human rights often requires domestic power-sharing arrangements. In such situations, federalism and human rights are clearly friends rather than foes.

\subsection{The Right to Self-Determination}

As far as federal systems serve to implement the right to self-determination of nations or peoples, multi-tier governance follows a human rights agenda. The right to self-determination of peoples is an aim of the United Nations ${ }^{49}$ and the only human right guaranteed in both UN human rights covenants. Peoples have an internationally guaranteed right 'to freely determine their political status and freely pursue their economic, social and cultural development. ${ }^{50}$ According to the High Commission for Human Rights, the right of selfdetermination 'is of particular importance because its realization is an essential condition for the effective guarantee and observance of individual human rights and for the promotion and strengthening of those rights. ${ }^{51}$ Insofar as the right to self-determination is implemented internally (and not externally, through secession namely), it requires some form of power-sharing between the different peoples of the same state. ${ }^{52}$

As establishing a federal system is one way of implementing the right to selfdetermination, it is surprising that UN Treaty Bodies - by recommending unified laws and uniform implementation - suggest limiting or abandoning such a regime. There can be no doubt that federal systems are a privileged mechanism for multinational states to respect the right to internal self-determination and to prevent separatists from turning into secessionist claims for external self-determination. At least for states hosting diverse peoples, federalismadverse or even hostile recommendations go against the spirit of Article 1 of the Covenants and thus against the mandate of the UN treaty bodies.

49 Art. 1 and Art. 55 UN Charter.

50 Art. 1 of both UN Covenants.

51 Human Rights Committee, CCPR General Comment No. 12: Article 1 (Right to SelfDetermination), the Right to Self-Determination of Peoples (1984), No. 1.

52 See e.g. Obiora Chinedu Okafor, "The International Law of Secession and the Protection of the Human Rights of Oppressed Substate Groups: Yesterday, Today and Tomorrow," in Nigerian Yearbook of International Law 2017, eds. Chile Eboe-Osuji and Engobo Emeseh (Cham: Springer International Publishing, 2018), 143 et seqq. 


\subsection{The Rights of Minorities}

The same is true for recommendations questioning minority rights arrangements. The Covenant on Civil and Political Rights obliges states with ethnic, religious or linguistic minorities to respect their right 'to enjoy their own culture, to profess and practice their own religion, or to use their own language' in community with the other members of their group. ${ }^{53}$ One way of protecting the interests of minorities and respecting their rights is to transfer powers to the respective regions or groups. ${ }^{54}$ Minorities concentrated in one or more regions of the country then do not depend on central authorities to enjoy their culture, religion and language but autonomously establish their own institutions and policies. The will to fully implement these minority rights can thus lead states characterised by diversity to preserve or to establish power-sharing regimes designed to accommodate the members of minority groups. In the case of minority groups, the strong link between human rights and autonomy becomes evident as self-rule and autonomy in some policy areas ultimately contribute to the fulfilment of human rights. The aim of such arrangements is not to create groups more privileged than others. It is rather to guarantee conditions in which minorities are able to enjoy human rights equally with other groups, to effectively prevent assimilation and to offer smaller groups entrenched mechanisms protecting them from being overruled by the majority in policy fields linked to their language, religion, culture and ways of life. ${ }^{55}$

This is in line with the UN Declaration of $1992^{56}$ requesting states to protect minorities, to promote their identities, and to adopt appropriate legislative and other measures (Article 1). The Declaration makes it clear that persons belonging to minorities have a right to enjoy and develop their culture, religion and language, the right to maintain their own associations and 'the right to participate effectively in decisions on the national and, where appropriate, regional level'. Although there are many ways to fulfil these obligations, federal states - which combine minority self-rule and participation in the establishment of shared rule - are certainly in line with the wording and spirit of the Declaration. When human rights bodies, in such contexts, recommend

53 Cf. art. 27 CCPR.

54 James A. Gardner, "In Search of Sub-National Constitutionalism," EuConst 4 (2008), 334; cf. also Watts, Comparing Federal Systems, 165 et seqq; Steytler, "The Constitutional Conversation Between the Federal Structure and a Bill of Rights", 7 .

55 Cf. Surendra Bhandari, Self-Determination \& Constitution Making in Nepal: Constituent Assembly, Inclusion, \& Ethnic Federalism (Singapore: Springer, 2014).

56 UN General Assembly, Declaration on the Rights of Persons Belonging to National or Ethnic, Religious and Linguistic Minorities, 3 February 1992, A/REs/47/135. 
establishing national laws, frameworks and actions plans, they risk encouraging states to impinge on the rights of minorities. This being said, it is undoubtedly true that the effective protection of all minorities, including small and scattered groups, requires additional measures as well as mechanisms ensuring that all subnational actors respect and promote the minority rights of all groups living on their territory.

\subsection{The Rights of Indigenous Peoples}

Finally, the protection of indigenous peoples' rights can push states to establish and develop autonomy arrangements. ${ }^{57}$ Indigenous peoples, often simultaneously qualifying as both peoples and minorities, enjoy specific protection by ILO Conventions ${ }^{58}$ and a UN Declaration (UNDRIP). Indigenous and tribal peoples have the right to the respect and protection of their identity, ${ }^{59}$ to special actions compatible with their aspirations and ways of life, 60 'special measures for safeguarding the persons, institutions, property, labour, cultures and environment of the peoples concerned'61 and a right to consultation and participation. ${ }^{62}$ The ILo Convention also states that indigenous peoples have 'the right to decide their own priorities for the process of development as it affects their lives, beliefs, institutions and spiritual well-being and the lands they occupy or otherwise use, and to exercise control, to the extent possible, over their own economic, social and cultural development.' ${ }^{63}$ In addition, 'they shall participate in the formulation, implementation and evaluation of plans and programmes for national and regional development which may affect them directly'.64

In short, the respect of indigenous rights requires states hosting such groups to establish a system of self-rule and shared rule - i.e. to create or maintain some sort of a federal system. Here again, the purpose of a specific powersharing arrangement responding to the needs of indigenous peoples does not promote political fragmentation but rather strengthens political unity by e.g.

57 See e.g. Mauro Barelli, "The Interplay Between Global and Regional Human Rights Systems in the Construction of the Indigenous Rights Regimes," Human Rights Quarterly 32, no. 4 (2010), 959 et seqq.

$5^{8}$ International Labour Organisation (ILO), Indigenous and Tribal Peoples Convention, C169, 27 June 1989 .

59 Art.1 ILO-Convention 169.

6o Art. 2 ILO-Convention 169.

61 Art. 4 ILO-Convention 169.

62 Art. 6 ILO-Convention 169.

63 Art. 7 ILO-Convention 169.

64 Art. 7 ILO-Convention 169. 
ensuring equal citizen rights to indigenous peoples (Article 6 UNDRIP). When it comes to respecting the rights of autochthonous peoples, human rights are the starting point and the endpoint of any power-sharing arrangements. Firstly, this is because local autonomy and self-rule is construed as a means to realise human rights effectively. Secondly, indigenous peoples' rights cannot be invoked discriminatorily against human rights of other people. Article 46(2) UNDRIP highlights that the exercise of indigenous peoples' rights is limited by the primacy of human rights of all people. ${ }^{65}$ In the context of indigenous peoples, federalism-adverse or -hostile recommendations of human rights bodies are nonsensical.

The respect and protection of the right to self-determination of peoples and minorities as well as indigenous peoples' rights often oblige states to establish a power-sharing regime or to make other arrangements to allow for diversity. The interlinkages and synergies between federalism and human rights, however, are far more general and deeper. After all, human rights can easily be proclaimed internationally, but they must always be lived locally. Universal rights remain very abstract and lifeless if they are not brought into action where people live, work, grow up and raise their children. Free and fair elections, fair trials, human treatment in prisons, decent labour conditions, and access to education and adequate health services are either guaranteed day after day locally - or do not reach most people. In many ways, multilevel governance, designed and implemented to bring government closer to the people and to make it more legitimate and effective, and multilevel human rights obligations, are predestined for long and lasting relationships.

Regional and local autonomy contributes to peaceful diversity management and has the potential to deepen democracy, to strengthen government accountability and to implement human rights responsively to regional and local priorities. It is thus worth advocating for subnational space in human rights even beyond the respect of the people's rights to self-determination and the protection of minority rights. Without the right to be different, autonomy and everything it stands for is not meaningful. If subnational actors are responsible for education, health, environment, police and social assistance, policies and laws will necessarily be different, and these differences will often affect the

65 Bhandari, Self-Determination \& Constitution Making in Nepal, 144 et seq. 
right to education, health, security and decent living conditions, giving them regional and local characteristics. Diversity in human rights protection, however, does not question the principle of equality. Equality just plays out differently in federations and other states based on regional and local autonomy.

While equality is often the ultimate guideline in unitary states, the respect for diversity and its constitutional protection are just as important in federal systems. The baseline of the duality of the objectives is that the concept of equality is understood and conceptualised differently. Federal constitutions and national laws are limited to establishing the minimum floor subnational units must respect but are invited to exceed. Regional as well as local actors are free to go beyond whatever overriding law obliges them to do; they are empowered to produce inequality as long as they improve standards and do not fall behind them. Just like international treaties, federal human rights catalogues thus refrain from providing comprehensive national human rights building in which all citizens are guaranteed equal conditions as they are only setting a minimum threshold. All citizens, irrespective of where they live, can claim these minimum standards. In addition, some but not necessarily all citizens may benefit from the extra efforts their region or municipality has made. This conventional wisdom of the minimum floor makes sense in international as well as in national multilevel systems. It must, however, be challenged as it does not convincingly answer all questions linked to multilevel human rights implementation. It can easily apply to the progressive implementation of human rights, in particular socio-economic rights (as long as there is agreement on definitions of progress versus steps backwards). It is conversely not apt to respond to more complex human rights controversies, in particular those involving several human rights dimensions and different conflicting human rights.

\subsection{Respect of the Minimum Floor as a Guarantee to All}

The paradigm of the minimum floor has always been part of international human rights law. International human rights treaties define minimum standards which contracting parties have to comply with but are allowed to exceed. Most international human rights treaties explicitly or implicitly contain rules prescribing such interpretation, making it clear that international standards cannot be understood as limiting rights and freedoms a person would otherwise enjoy. ${ }^{66}$ International human rights standards thus entrench and complement domestic rights and freedoms by adding a minimum floor - not a

66 See e.g. article 6o of European Convention of Human Rights: "Nothing in this Convention shall be construed as limiting or derogating from any of the human rights and fundamental 
ceiling. States bound by international human rights law thus have to respect the treaty but are under no obligation to apply uniform human rights standards. The internationally guaranteed rights and freedoms must be regarded as minimum standards with the aim of harmonising, not unifying, human rights practices. In no way should international guarantees hinder or crush domestic laws guaranteeing more rights and freedoms or protecting and implementing them more effectively.

Federal states reiterate the international human rights system internally. They add their own national minimum standards, which must necessarily respect the international ones but can go beyond it, and the subnational units must implement it but are allowed to improve it. In fact, multilevel human rights protection takes the shape of a pyramid in the federal system as it becomes stronger and broader at the bottom. It is not a column implementing the same standards on the local, regional and national level. For this reason, human rights operate differently in federations. While unitary states implement uniform human rights standards applicable throughout the country, federal states define a minimum standard that all subnational actors must comply with but may improve on. The federal protection of civil, political, economic, social and cultural human right sets a federal floor of rights, which allows for 'diversity only above and beyond this federal constitutional floor' ${ }^{67}$ Setting a minimum floor of rights prohibits subnational units from falling behind the standard (which would violate overriding law and transform the column into a kind of hopper) but it does not prevent regional and local actors from improving on such a floor. It rather invites them to do so. ${ }^{68}$

Two situations often confounded in theory and practice must therefore be distinguished. In the first, a subnational actor falls behind the federal constitutional floor or international human rights standards. The unequal treatment of citizens, in this case, does not stem from the use of autonomy but rather from its misuse; it is not a result of subnational policy and law-making but of failing national law implementation. As mentioned above, such a situation, which is in breach of overriding law, must be remedied by courts or by the use

freedoms which may be ensured under the laws of any High Contracting Party or under any other agreement to which it is a Party."

67 Brennan, JR., "The Bill of Rights and the States", 550.

68 Kincaid, "Values and Value Tradeoffs in Federalism", 252; similar also Kristin Henrard, "Equality Considerations and Their Relation to Minority Protections, State Constitutional Law, and Federalism," in Federalism, Subnational Constitutions, and Minority Rights, eds. George A. Tarr, Joseph Marko and Robert F. Williams (Westport CT: Praeger, 2004), 35 et seq. 
of supervisory and intervention powers. In the second situation, diversity and thus inequality - results from the fact that a subnational actor has acted beyond the minimum floor. Such inequality is as acceptable within a state as it is between states. No human rights actor should frown at it but rather appreciate the innovation and effort coming from regional and local actors.

\subsection{The Right to Go beyond the Minimum}

Subnational constitutions regularly have their own human rights catalogues, which cannot fall behind international and national ones but may go beyond. In these constitutions and also in law and practice, subnational governments can perform their famous role as laboratories for innovation and experimentation' in which new ideas can be tested at the regional level and, if successful, be copied by others and inspire national and international innovation. ${ }^{69}$ There is abundant evidence of the successful use of this role. ${ }^{70}$ The constitution of the state of Córdoba, for instance, granted women's rights in 1927, long before the federal constitution did the same. While it is well known that the Swiss Cantons of Appenzell Innerhoden unconstitutionally refused to introduce female suffrage, it is also true that numerous cantons introduced it long before the federal constitution did.

There is also evidence that national actors enforcing unified human rights concepts have sometimes prevented subnational governments from progressing. There is no doubt that national actors are crucial actors in enforcing (minimum) human rights standards and preventing subnational governments from violating binding standards. It would however be erroneous to conclude that they are necessarily the source of human rights innovation. As they can also operate as breaks and slow down human rights progress, checks and balances and multiple power centres are important devices to make human rights evolution more resilient. Famously, the Supreme Court of the United States held in the Dred Scott case of 1857 that a federal law purporting to ban slavery from

69 Kincaid, "Values and Value Tradeoffs in Federalism", 253; Wyttenbach, Umsetzung von Menschenrechtsübereinkommen in Bundesstaaten, 145 et seqq; Subnational human rights catalogues are not only laboratories for innovation, but also establish a (competing) legal protection system at the subnational level, which is of particular importance when national and international levels of human rights protection fail to meet their respective obligations. See Gardner, "In Search of Sub-National Constitutionalism", 341.

70 Cf. e.g., Peter W. Hogg, Constitutional Law of Canada student ed. (Toronto: Carswell, 2009), 705 et seqq.; Andrew Wolman, "The Relationship Between National and Sub-national Human Rights Institutions in Federal States," The International Journal of Human Rights 17, no. 4 (2013); Mahendra P. Singh, "Federalism, Democracy and Human Rights: Some Reflections," Journal of the Indian Law Institute 47, no. 4 (2005), 429 et seqq. 
certain parts of the United States could not have the effect of freeing slaves brought into those states, because that would constitute a deprivation of the slave owner's property rights. ${ }^{71}$ The due process clause of the American Bill of Rights thus became an obstacle to the emancipation of slaves, which was only removed by a constitutional amendment after the civil war. Another notorious case, decided by the same court in 1905, is Lochner in which the Supreme Court struck down a New York law limiting working hours in a bakery to 6o per week and 10 per day. The court held that the state law violated the due process clause by denying the liberty of the employer to contract with his workers on the terms of his choice. ${ }^{72}$ The Lochner case is just one of hundreds of cases in which the Supreme Court applied a broad notion of property, liberty and due process to strike down state laws adapted to protect the right to liberty of all, the health and wages of workers, and the right of assembly of unionists. Only after President Roosevelt announced his plan to pack the court with more justices, did the court start to change its mind and allow the New Deal to improve socio-economic rights. ${ }^{73}$

Like most constitutional courts, the Swiss Federal Supreme Court has consistently held that cantonal fundamental rights might have independent significance if they provide protection going beyond the fundamental rights provided by the Federal Constitution or if they guarantee a right that is not enshrined in the Federal Constitution. ${ }^{74}$ While some cantons are content with referring to the human rights protected by federal and international law ${ }^{75}$ and show little interest in improving on it, others cantons have opted for a human rights catalogue that goes beyond what is guaranteed on the upper level. ${ }^{76}$ Nine cantons guarantee the right to choose freely any form of living together in partnership. ${ }^{77}$ Other cantons decided to extend the scope of political rights on the cantonal level. While on a federal level, Swiss citizens have to be 18 years

71 Dred Scott v. Sandford, 6o U.S. (19 How.) 393 (1856).

72 Lochner v. New York, 198 U.S. 45 (1905).

73 See Hogg, Constitutional Law of Canada, 731.

74 Cf. e.g., Decision of the Swiss Federal Court, BGE 121 I 267, 269.

75 Cf. e.g., para. 10(2) Constitution of the Canton of Lucerne, para. 1o Constitution of the Canton of Schwyz or art. 7 and 8 Constitution of the Canton of Grisons; cf. Andreas Auer, Staatsrecht der schweizerischen Kantone (Bern: Stämpfli Verlag, 2016), No. 1448.

76 Gardner, "In Search of Sub-National Constitutionalism", 335.

77 Art.13 Constitution of the Canton of Zurich; art.13(2) Constitution of the Canton of Berne; art. 14(2) Constitution of the Canton of Fribourg; para. 11(1i) Constitution of the Canton of Basel-Stadt; art. 12(1c) Constitution of the Canton of Schaffhausen; art. 10(2) Constitution of the Canton of Appenzell Ausserrhoden; art. 14(2) Constitution of the Canton of Vaud; art. 12(2) Constitution of the Canton of Neuchâtel and art. 22 Constitution of the Canton of Geneva; cf. Auer, Staatsrecht der schweizerischen Kantone, No. 1451. 
or older to vote, ${ }^{78}$ the Canton of Glarus already allow 16 - and 17-year-olds to vote on cantonal and communal matters. ${ }^{79}$ Similarly, some - mostly francophone - cantons grant the right to vote to non-Swiss citizens in cantonal and communal ballots. ${ }^{80}$ In the United States, the subject of same-sex marriage became prominent when the Hawaii Supreme Court decided in 1993 that the state's prohibition of same-sex marriage might be unconstitutional. ${ }^{81}$ In 2004, the mayor of San Francisco issued the first marriage licence to a same-sex couple; the same year Massachusetts became the first state to legalise same-sex marriage. ${ }^{82}$ The consequence of extra efforts by subnational actors is inequality: in some cantons, non-Swiss nationals are allowed to participate in elections, whereas in others, such rights are strictly limited to Swiss nationals. In some cantons, same-sex couples or elderly people enjoy extra protection; in others, their rights are limited to what the federal constitution has to offer. ${ }^{83}$ In all these situations, imposing equality throughout the country would lower the overall human rights achievements of the country and raise human rights standards to the bottom, not the top. Most of these innovations and expansion of rights are subnational exactly because there is no sufficient consensus in the country (yet) to adopt them on the national level. For the time being, voting rights for non-nationals are unlikely to be introduced nationally. The same can be said for voting rights from the age of 16 years, the recognition of all forms of family lives, special human rights mandates to respect the autonomy of elderly people, to cite a few examples. In all these situations, the existence of uniform standards prevents more progressive cantons from making a step forward and inspiring others.

Cantonal innovations reach beyond special guarantees and affect human rights implementation mechanisms as well: some governments have established human rights ombudspersons or new mechanisms to strengthen human

78 Art. 136(1) Swiss Federal Constitution; cf. also art. 25 CCPR which states that political rights can only be exercised under the condition of being a citizen of the state.

79 Art. 56(1) Constitution of the Canton of Glarus.

80 Cf. e.g., art. 37( $1 \mathrm{~b}$ and c) Constitution of the Canton of Neuchâtel and art. 2(c) and 3(c) of the cantonal Act on Political Rights; art. 73 Constitution of the Canton of Jura and art. 3 of the cantonal Act on Political Rights.

81 Baehr v. Lewin, 74 Haw. 530, 852 P.2d 44 (Haw. 1993).

82 The legalisation was a reaction to the Massachusetts Supreme Judicial Court decision of the same year: Goodridge v. Department of Public Health, 798 N.E.2d 941 (Mass. 2003).

83 Cf. for protecting same-sex couples above and beyond the national layer of human rights protection, Fn. 65; special fundamental rights protecting the rights of elderly people can be found in art. 35 Constitution of the Canton of Fribourg and para. 16(2) Constitution of the Canton of Basel-Landschaft. 
rights mainstreaming, they have made extra efforts to support civil society and other crucial actors, or have come up with special reporting systems, round tables, participatory projects and the like. ${ }^{84}$ Obviously, all these innovations have the particularity of being limited to only one or a few cantons, at least at the beginning, and bring territorial inequality into the human rights system.

Subnational constitutions may also experiment with new or more strictly enforced social and economic rights. ${ }^{85}$ In Switzerland and Germany for instance, some cantons and Länder have included socio-economic rights imposing positive obligations beyond the national consensus. They have guaranteed rights to free education, for instance in the field of early childcare, tertiary education, continuous education or catch-up training. Some have also been more progressive than the national government in guaranteeing standards in the field of the right to housing, health care, social assistance, or the right to decent and sufficient work. ${ }^{86}$ Recently, the canton of Neuchâtel decided to introduce a minimum wage for its population and to undertake actions against poverty amongst workers. ${ }^{87} \mathrm{~A}$ similar plan, proposed by a popular initiative on the federal level, failed in 2014. ${ }^{88}$ In 2017, the Federal Supreme Court decided on appeal that the failure of the 'Minimum Wage Initiative' on the national level did not prevent a canton from taking similar initiatives on its own. ${ }^{89}$ It thereby accepted the idea that the population of one canton benefits from labour rights not guaranteed in other cantons.

Numerous countries guaranteeing local autonomy witness a multitude of human rights innovation on the city level. Since 2000, the number of Human Rights Cities has increased and numerous initiatives, especially in the field of economic, social and cultural rights, have emerged from them. ${ }^{90}$ Human Rights Cities and other local initiatives may create inequality between citizens of different local entities within the same state, but also offer the great chance

84 Cf. e.g., the Canton of Berne which has created an ombudswoman's office for issues related to age, care and institutions in 2003, the Canton of Geneva has had a Cantonal Human Rights Commission since 2000 or the Canton of Zurich which introduced a round table against human trafficking in 2001.

85 Auer, Staatsrecht der schweizerischen Kantone, No. 1484 et seqq.

86 Cf. Fercot, "Perspectives on Federalism", 314; cf. also for Switzerland, Auer, Staatsrecht der schweizerischen Kantone, No. 1489.

87 The Federal Assembly validated art. 34(a) Constitution of the Canton of Neuchâtel by Federal Decree on 11 March 2013. By doing so, it confirmed that the cantonal constitutional provision is in accordance with federal law, cf. BBl 2013 2617, 2618.

88 Federal Decree on the result of the referendum of 18 May 2014, BBl 2014 6349, 635 ०.

89 Decision of the Swiss Federal Court, BGE 143 I 403.

90 Cf. the activities of the World Organisation of United Cities and Local Governments (CGLU) in the field of human rights, such as the World Human Rights Cities Forum. 
of improving the life of residents and creating good and better practices which can serve as sources of innovation for others.

Some subnational governments have even experimented with thirdgeneration human rights. While countries such as Austria, Canada, Germany and the United States have provisionally closed the door to constitutionalising substantive environmental rights, some regions in these countries have decided otherwise and included the right to a healthy environment in their constitutions. ${ }^{91}$ Others have recognised a right to peace and intercultural dialogue. ${ }^{92}$ In recent years, some subnational actors have also shown more willingness to deal with human rights violations of the past and have come up with institutions, processes and ideas of how to make up for historic wrongs, such as administrative custody for poor and marginalised people, forced sterilisations and adoptions. Some regional governments have, before the federal one, opted for official apologies, mandated research, supported victims and taken commemorative and preventive measures. ${ }^{93}$ If federal countries would follow the federalism-adverse and -hostile recommendations and adopt uniform standards, such initiatives would no longer be possible.

\subsection{The Need to Revisit the Paradigm of the Minimum Floor}

While it is easy to conclude that it can be beneficial to accept unequal human rights standards in federal states, the question of how far inequality can go remains open. ${ }^{94}$ Is it acceptable to allow for the death penalty in some regions but not in others? Is it possible that the right to die is guaranteed in some parts of the country but not in others? Is it conceivable that same-sex couples can marry and adopt children in some regions but not in others and do we have to

91 Subnational units in Brazil, Canada, Germany, and the United States explicitly guarantee a right to a quality environment. Cf. James R. May and Erin Daly, Global Environmental Constitutionalism (New York: Cambridge University Press, 2016), 71 et seqq. See for an example Art. 19 Constitution of the Canton of Geneva.

92 Art. 7 Constitution of the Canton of Zurich.

93 The Governor of California for instance apologised to the more than 20,0oo people who were involuntarily sterilised under a eugenics program which operated until 1964, and the provincial government of British Columbia apologised to all Canadians who had suffered severe emotional and sexual abuse while in homes for developmentally disabled. Elazar Barkan and Alexander Karn, "Group Apology as an Ethical Imperative", in Taking Wrongs Seriously: Apologies and Reconciliation, eds. Elazar Barkan, Alexander Karn (Standford: Stanford University Press, 20o6), 6. Cf. also Ronald Rudin, Kouchibouguac: Removal, Resistance, and Remembrance at a Canadian National Park (Toronto: University of Toronto Press, 2016).

Kincaid, "Values and Value Tradeoffs in Federalism", 252 et seq. 
accept the idea that standards in education and health are different and equal citizenship not fully enforced?

The paradigm of the minimum floor is surely helpful in answering some of these questions. In the field of progressive duties, each competent actor has to take all appropriate measures to work for the full implementation of all economic, social and cultural rights. Differences will automatically result and are acceptable as long as all actors fulfil the minimum standards provided by international and national law. There is no reason to prevent a region from exceeding these and fulfilling its obligations more rapidly and more fully. The same can be said for regional and local political rights, such as regional and local consultations and referenda, and procedural rights, such as child-friendly justice or free simultaneous translation for foreigners.

Quite often, however, matters are more complex. This is the case whenever there is disagreement on the minimum floor and how it is to be interpreted (statically or dynamically) and by whom and whether it allows for exceptions (for cultural or other reasons). It is also the case when there are controversies over the question of whether a regional initiative is to be considered a human rights progress or regress. Whenever more than one human right is involved, the classic theory of the national minimum standard which can be exceeded by subnational actors is incapable of solving these disputes. In fact, the paradigm of the minimum floor has severe shortcomings and is not helpful in managing multilevel human rights implementation whenever there is a conflict between different human rights, for instance when religious freedoms clash with free speech, the right to privacy or the right to equality. Does a subnational actor introducing a burka ban (as the cantons of Ticino and St Gallen have recently done) improve gender equality, as they claim, or rather violate religious freedoms and discriminate against Muslim women?95 Does a subnational actor forcing bakers to sell wedding cakes to same-sex couples improve the right to non-discrimination or violate religious freedoms? ${ }^{96}$ Does a subnational entity regulating political financing improve political rights or impinge on the freedoms of political and economic activity?97 Does a canton prohibiting sexist advertising promote gender equality more effectively than other cantons do or does it violate the right of enterprises to speak and act freely? ${ }^{98}$

95 Cf. Stephan Zlabinger, "Schleierhafte Gesetzgebung? - Das St. Galler Gesichtsverhüllungsverbot unter dem Aspekt der Rechtsgleichheit in der Rechtsetzung," ZBl 119 (2018), 584 and 59 o et seqq.

96 Cf. Masterpiece Cakeshop, Ltd. v. Colorado Civil Rights Commission, 584 U.S. (2018).

97 Decision of the Swiss Federal Court, BGE 125 I 441.

98 Cf. the Parliament of the Canton of Vaud which adopted unanimously - with one abstention - a new provision which will prohibit any advertising of sexist content, see for more 
In addition, the minimum floor theory also fails when there is a tension between different human rights duties, such as the duty to respect, protect and fulfil rights and freedoms. If a subnational unit guarantees the right to die does it then improve human rights standards by respecting a person's personal freedom to decide on the time or way of their own death or does it instead neglect the duty to protect the right to life of all by creating the risk that people rush into assisted suicide or are pushed into it by self-interested family members? If a region prohibits abortion, does it improve the protection of the right to life or does it fall behind the minimum floor of respect due to the freedom rights of the pregnant woman? ${ }^{99}$

All these examples demonstrate that the minimum floor theory falls short of the mark. First, the different dimensions of each human right all have different minimum floors. The duties to respect individual rights and freedoms and not to interfere, to actively protect from dangers and to progressively fulfil human rights fully and for all have their own minimum requirements and all these floors continually evolve. The duty to respect privacy is probably more easily standardised than the duty to protect privacy in the private sphere. But the duties to protect can still more easily be harmonised than the duties to progressively fulfil it throughout the legal system and to adapt it to new societal and technological challenges. Second, most human rights conflicts are complex and involve more than one human right. The identification of the floor and the decision whether a regional law or decision builds on it or violates it, are then even more controversial.

In sum, the conventional answer - subnational actors can go beyond international and national human rights standards but are not allowed to fall behind - is not sufficient. The mediation between local, regional, national and international approaches to human rights is far more complex. In order to improve the relations between federalism and other forms of multilevel governance and human rights, we need to increase our understanding of multilevel human rights governance. ${ }^{100}$ Surely, some inspiration can be derived from the way constitutional or federal courts use their adjudication power.

information: humanrights.ch, "Der Kanton Waadt verbietet sexistische Werbung im öffentlichen Raum", https://www.humanrights.ch/de/menschenrechte-schweiz/inneres/ frau-mann/gleichstellung/sexistische-werbung, (accessed 7 July 2019).

99 Cf. e.g., the developments on the state level in Mexico and Australia, Reed Boland and Laura Katzive, "Developments in Laws on Induced Abortion:1998-2007," International Family Planning Perspectives 34, no. 3 (2008), 113 and 114.

100 Samantha Besson, "Droits de l'homme et fédéralisme: une introduction thématique", in Die Europäische Menschenrechtskonvention und die Kantone, eds. Samantha Besson and Eva Maria Belser (Geneva, Zurich, Basel: Schulthess, 2014), 32. 
What threshold do they apply? And how much margin of appreciation do they leave to subordinate actors? Do they unify or harmonise human rights and in what field and why do they opt for the former and the latter? On the international level, the European Court of Human Rights must answer the very same questions, although based on the limited catalogue of the European Convention of Human Rights, which only guarantees civil and political, but not economic, social or cultural rights. Based on its limited mandate of implementing minimum human rights standards, it has developed a practice on the intensity of its scrutiny that is as controversial as it is sophisticated. ${ }^{101}$ The margin of appreciation is dependent on the human right involved and is stricter in the field of inhuman treatment, procedural rights, free speech and nondiscrimination than it is in the field of religion and family law where cultural differences play a more prominent role. ${ }^{102}$ It also depends on the human right dimensions involved; as a rule, the duty to respect requiring non-interference is more uniformly applied than is the duty to protect which demands that states take all appropriate measures to prevent human rights interferences by a private actor. Most importantly, the level of scrutiny depends on the existence or absence of a European consensus. ${ }^{103}$ It is on this consensus that the dynamic evolution of the European human rights catalogue is based. What a member state is bound to comply with thus also depends on what other member states are doing and what progress they are making. For the living tree document to live and flourish, inputs must hence come from its national sources. Uniform standards imposed from above would cripple these sources and impede further bottom-up human rights evolutions. ${ }^{104}$ The same logic of

101 Andreas Follesdal and Nino Tsereteli, "The Margin of Appreciation in Europe and Beyond," The International Journal of Human Rights 20, no. 8 (2016), 1055 (with further references) or Samantha Besson, "Subsidiarity in International Human Rights Law - What Is Subsidiary About Human Rights?," The American Journal of Jurisprudence 61, no. 1 (2016), 73 (with further references).

102 Cf. Eva Maria Belser, "Kantonale Grundrechte," 87; see also the findings of Luzius Wildhaber, Arnaldur Hjartarson, and Stephen Donnelly, "No Consensus on Consensus? The Practice of the European Court of Human Rights," Human Rights Law Journal 33 (2013), 259 et seqq.

103 Cf. e.g., Eyal Benvenisti, "Margin of Appreciation, Consensus, and Universal Standards," New York University Journal of International Law and Politics 31, no. 4 (1999) or Wildhaber, Hjartarson and Donnelly, "No Consensus on Consensus?"

104 Cf. Amrei Müller, "Domestic Authorities' Obligations to Co-Develop the Rights of the European Convention on Human Rights," The International Journal of Human Rights 20, no. 8 (2016), 1059 or Besson, "Subsidiarity in International Human Rights Law - What is Subsidiary about Human Rights?", 100. 
multilevel dialogues between innovative (and sometimes failing) states and controlling supranational entities must apply within federal states.

\section{6}

\section{Conclusions: A Promising Partnership}

Various reports and recommendations issued by UN treaty bodies emphasise that the national government, in the case of Switzerland the Confederation, has the primary responsibility to ensure the domestic implementation of the conventions. ${ }^{105}$ Undoubtedly, solely the federal tier has the duty to report and follow-up on international recommendations. ${ }^{106}$ Whether one can conclude that the federal tier carries the 'primary responsibility' is however doubtful. Externally, the federal government, representing the Swiss Confederation in its entirety, is obviously the guarantor for the fulfilment of international law. Internally, the federal government is, however, often not, or not exclusively, competent to realise treaty obligations. In the field of human rights in particular, international obligations often affect cantonal and municipal competences. Such is, for instance, the case in the field of the right to education, housing, health services, social aid, police and prisons or integration policies. Other human rights obligations, such as the right to information or the full and comprehensive implementation of gender equality, require efforts from all state actors on all tiers. ${ }^{107}$

In its general comment No. 3 (1990) to the Covenant on economic, social and cultural rights, the Committee rightly states that it is its role to ultimately determine whether a state has taken all appropriate measures to implement the obligations of the Covenant. Just as importantly, it states that 'each State party must decide for itself which means are the most appropriate under the circumstances with respect to each of the rights. ${ }^{108}$ Unfortunately, most treaty

105 CESCR, Concluding Observations, E/C.12/CHE/CO/2-3 (2010), para. 5; CEDAw, Concluding Observations, CEDAW/C/C HE/CO/3 (2009), para. 10 and 2O; Committee on the Elimination of Racial Discrimination, Consideration of Reports Submitted by States Parties Under Article 9 of the Convention: Concluding Observations of the Committee on the Elimination of Racial Discrimination, Switzerland, CERD/C/CHE/CO/6 (2OO8), para. 8.

106 Cf. Art. 54 and 184 Swiss Federal Constitution.

107 Schweizerischen Kompetenzzentrums für Menschenrechte, Die periodische Überprüfung der Menschenrechtslage der Schweiz (UPR): Eine Zwischenbilanz nach drei Zyklen (Bern: 2018), 12; Belser and Mazidi, "Das Zusammenwirken von Bund und Kantonen bei der Einhaltung völkerrechtlicher Menschenrechtsverpflichtungen der Schweiz", 245.

108 Committee on Economic, Social and Cultural Rights, General Comment No. 3: The Nature of States Parties' Obligations (Art. 2, Para. 1, of the Covenant): E/1991/23 (1990), No. 4; cf. also CESCR, General Comment No. 9, E/C.12/1998/24 (1998), No. 5: 'Although the precise 
bodies tend to disregard the general comment. As far as and as long as states take all appropriate measures, international bodies have no reason to interfere with the country's internal organisation.

Human rights obligations mandating the respect of diversity - and implicitly requiring some form of autonomy - make it evident that approaches focusing on multi-level government, on the one hand, and approaches concerned with human rights for all, on the other hand, are not following contradictory aims, which must be mitigated. They rather share common concerns and interests. Conventional wisdom suggesting that promoting self-determination for peoples and minority rights and protecting human rights of individuals are competing priorities is thus erroneous. It is also inappropriate to propose balancing the two. Such proposals imply that securing individuals in their human rights requires special limits on the rights of their peoples or the groups they belong to, and vice versa. In contrast, federalism and human rights, as has been shown above, are often in a win-win-relation, in which the strengthening of one approach does not come at the price of weakening the other.

Diversity, even in the sensitive field of human rights, is not per se a problem to overcome but a situation to handle within the framework of national and international human rights obligations. Different human rights standards can be acceptable, desirable or even required by human rights. On the one hand, human rights implementation can call for the respect of collective autonomy; on the other hand, the combination of self- and shared rule can be conducive to human rights implementation and create productive multilevel feedback loops.

There is, however, a need for more differentiation. It may be in line with international human rights obligations to accept or promote different linguistic or cultural rights for different regions and to allow autonomous regions to go beyond minimum standards in the field of social and economic rights. The same does not necessarily apply to certain civil rights and liberties, such as the right to a fair trial or the right to non-discrimination, where uniform standards may be required. Different rules for different human rights and different human rights obligations are thus needed and the leeway of subnational actors and their margin of appreciations must be clarified in a differentiated and dynamic way.

method by which Covenant rights are given effect in national law is a matter for each State party to decide, the means used should be appropriate in the sense of producing results which are consistent with the full discharge of its obligations by the State party. The means chosen are also subject to review as part of the Committee's examination of the State party's compliance with its obligations under the Covenant.' 
The potential partnership between federalism and human rights, often characterised by scepticism and distrust, would surely improve if communication were more open and intense. International treaty bodies typically only take an interest in internal power-sharing when one or several subnational or local actors fail to respect human rights. A limited focus on shortcomings, however, disregards the great potential of bottom-up solutions and oversees the numerous examples of special regional and municipal achievements. The assessment of the effects of federalism on human rights should thus be more comprehensive and look at violations as well as improvements. These are the progresses which source international consensus and eventually enable the rise of minimum standards. Tracking regional and local progress, appreciating it nationally and valorising it internationally are also prerequisites for transnational learning. Good and best practices are made available to other subnational and local actors, feed into international reports and recommendations and enter into recommendations made to other states. A more comprehensive assessment thus allows multilevel learning and feedback loops, necessary for the participatory, inclusive, and local implementation of universal rights. Even though the relations between constitutional guarantees of regional and local autonomy and human rights have been uneasy in the past, it seems worth trying again in the future.

\section{Bibliography}

Auer, Andreas. Staatsrecht der schweizerischen Kantone. Bern: Stämpfli Verlag, 2016.

Barelli, Mauro. "The Interplay Between Global and Regional Human Rights Systems in the Constrution of the Indigenous Rights Regimes." Human Rights Quarterly 32, no. 4 (2010): 951-79.

Barkan, Elazar, and Alexander Karn. "Group Apology as an Ethical Imperative." In Taking Wrongs Seriously: Apologies and Reconciliation, edited by Elazar Barkan and Alexander Karn, 3-30. Standford: Stanford University Press, 2006.

Bell, Koren L. "From Laggard to Leader: Canadian Lessons on a Role for U.S. States in Making and Implementing Human Rights Treaties." Yale Human Rights and Development Law Journal 5, no. 1 (2002): 255-91.

Belser, Eva Maria "Kantonale Grundrechte und ihre Bedeutung für die Verwirklichung der Menschenrechte im mehrstufigen Staat." In Die Europäische Menschenrechtskonvention und die Kantone, edited by Samantha Besson and Eva Maria Belser, 67-93. Geneva, Zurich, Basel: Schulthess, 2014.

Belser, Eva Maria, and Simon Mazidi. "Das Zusammenwirken von Bund und Kantonen bei der Einhaltung völkerrechtlicher Menschenrechtsverpflichtungen der Schweiz." 
In Jahrbuch des Föderalismus 2018: Föderalismus, Subsidiarität und Regionen in Europa, edited by Europäisches Zentrum für Föderalismus-Forschung Tübingen (EZFF), 243-57. Baden-Baden: Nomos, 2018.

Benvenisti, Eyal. "Margin of Appreciation, Consensus, and Universal Standards." New York University Journal of International Law and Politics 31, no. 4 (1999): $843-54$.

Besson, Samantha. "Droits de l'homme et fédéralisme une introduction thématique." In Die Europäische Menschenrechtskonvention und die Kantone, edited by Samantha Besson and Eva Maria Belser, 7-39. Geneva, Zurich, Basel: Schulthess, 2014.

Besson, Samantha "Subsidiarity in International Human Rights Law - What Is Subsidiary About Human Rights?" The American Journal of Jurisprudence 61, no. 1 (2016): 69-107.

Bhandari, Surendra. Self-Determination \& Constitution Making in Nepal: Constituent Assembly, Inclusion, \& Ethnic Federalism. Singapore: Springer, 2014.

Boland, Reed, and Laura Katzive. "Developments in Laws on Induced Abortion: 19982007." International Family Planning Perspectives 34, no. 3 (2008): 110-20.

Brennan, William J., JR. "The Bill of Rights and the States: The Revival of State Constitutions as Guardians of Individual Rights." New York University Law Review 61, no. 4 (1986): 535-53.

Cameron, Jamie. "Federalism, Treaties, and International Human Rights Under the Canadian Constitution." Wayne Law Review 48, no. 1 (2002): 1-55.

Committee against Torture. Consideration of Reports Submitted by States Parties Under Article 19 of the Convention: Concluding Observations of the Committee Against Torture, Switzerland, CAT/C/CHE/CO/6. 2010.

Committee against Torture. Concluding Observations on the Seventh Periodic Report of Switzerland, CAT/C/CHE/CO/7.2015.

Committee on Economic, Social and Cultural Rights. General Comment No. 9: The Domestic Application of the Covenant, E/C.12/1998/24. 1998.

Committee on Economic, Social and Cultural Rights. Consideration of Reports Submitted by States Parties Under Articles 16 and 17 of the Covenant: Concluding Observations of the Committee on Economic, Social and Cultural Rights, Switzerland, E/C.12/CHE/CO/2-3. 2010.

Committee on Economic, Social and Cultural Rights. General Comment No. 3: The Nature of States Parties' Obligations (Art. 2, Para. 1, of the Covenant), E/1991/23. 199 o. Committee on the Elimination of Discrimination against Women. Concluding Observations of the Committee on the Elimination of Discrimination Against Women: Belgium, CEDAW/C/BEL/CO/6. 2008.

Committee on the Elimination of Discrimination against Women. Concluding Observations of the Committee on the Elimination of Discrimination Against Women: Canada, CEDAW/C/CAN/CO/7. 2008. 
Committee on the Elimination of Discrimination against Women. Concluding Observations of the Committee on the Elimination of Discrimination Against Women: Switzerland, CEDAW/C/CHE/CO/3. 2009.

Committee on the Elimination of Discrimination against Women. Concluding Observations on the Combined Eighth and Ninth Periodic Reports of Canada, CE DAW/ C/CAN/CO/8-9. 2016.

Committee on the Elimination of Discrimination against Women. Concluding Observations on the Combined Fourth and Fifth Periodic Reports of Switzerland, CEDAW/C/CHE/CO/4-5. 2016.

Committee on the Elimination of Racial Discrimination. Consideration of Reports Submitted by States Parties Under Article g of the Convention: Concluding Observations of the Committee on the Elimination of Racial Discrimination, Switzerland, CERD/C/ $\mathrm{CHE} / \mathrm{CO} / 6.2008$.

Committee on the Rights of the Child. Concluding Observations on the Combined Second to Fourth Periodic Reports of Switzerland, CRC/C/CHE/CO/2-4. 2015.

Ebobrah, Solomon, and Felix Eboibi. "Federalism and the Challenge of Applying International Human Rights Law Against Child Marriage in Africa." Journal of African Law 61, no. 3 (2017): 333-54.

Fercot, Céline. "Perspectives on Federalism: Diversity of Constitutional Rights in Federal Systems." European Constitutional Law Review 4, no. 2 (2008): 302-24.

Follesdal, Andreas, and Nino Tsereteli. "The Margin of Appreciation in Europe and Beyond." The International Journal of Human Rights 20, no. 8 (2016): 1055-57.

Gardner, James A. "In Search of Sub-National Constitutionalism." EuConst 4 (2008):325-43. Gibbins, Roger, Rainer Knopff, and Frederick L. Morton. "Canadian Federalism, the Charter of Rights, and the 1984 Election." Publius: The Journal of Federalism 15, no. 3 (1985): 155-70.

Henrard, Kristin. "Equality Considerations and Their Relation to Minority Protections, State Constitutional Law, and Federalism." In Federalism, Subnational Constitutions, and Minority Rights, edited by George A. Tarr, Joseph Marko and Robert F. Williams, 25-39. Westport CT: Praeger, 2004.

Hogg, Peter W. "Federalism Fights the Charter of Rights." In Federal and Political Community: Essays in Honour of Donald Smiley, edited by David P. Shugarman and Reginald Whitaker, 249-66. Peterborough: Broadview Press, 1989.

Hogg, Peter W. Constitutional Law of Canada. Student ed. Toronto: Carswell, 2009.

Human Rights Committee. CCPR General Comment No. 12: Article 1 (Right to SelfDetermination), the Right to Self-Determination of Peoples. 1984.

Human Rights Committee. Concluding Observations on the Fourth Periodic Report of Switzerland, CCPR/C/CHE/CO/4. 2017.

Human Rights Council. Report of the Special Rapporteur on Adequate Housing as a Component of the Right to an Adequate Standard of Living, and on the Right to Nondiscrimination in This Context, Leilani Farha, A/HRC/28/62. 2014. 
Keller, Helen, and Geir Ulfstein. UN Human Rights Treaty Bodies: Law and Legitimacy. Cambridge: Cambridge Univ. Press, 2012.

Kincaid, John. "Values and Value Tradeoffs in Federalism." In Federalism: Volume 1: Historical and Theoretical Foundations of Federalism, edited by John Kincaid, 241-57. Sage library of political science. Los Angeles: SAGE, 2011.

Marx, Axel, Nicolas Hachez, Katrien Meuwissen, Pierre Schmitt, Kolja Raube, Jakub Jaraczewski, Joanna Roszak, Tamara Lewis, Klaus Starl, Maria Dolores Morondo Taramundi, Anna-Kaisa Tuovinen and Amy Weatherburn. Multilevel Protection of the Rule of Law and Fundamental Rights: The Role of Local and Regional Authorities and of the Committee of the Regions. European Union, 2014.

May, James R., and Erin Daly. Global Environmental Constitutionalism. New York: Cambridge University Press, 2016.

Morton, Frederick L., and Rainer Knopff. The Charter Revolution and the Court Party. Peterborough: Broadview Press, 2000.

Müller, Amrei. "Domestic Authorities' Obligations to Co-Develop the Rights of the European Convention on Human Rights." The International Journal of Human Rights 20, no. 8 (2016): 1058-76.

Okafor, Obiora Chinedu. "The International Law of Secession and the Protection of the Human Rights of Oppressed Substate Groups: Yesterday, Today and Tomorrow." In Nigerian Yearbook of International Law 2017, edited by Chile Eboe-Osuji and Engobo Emeseh, 143-69. Cham: Springer International Publishing, 2018.

Palermo, Francesco, and Karl Kössler. Comparative Federalism: Constitutional Arrangements and Case Law. Portland, Oregon: Hart Publishing, 2017.

Rudin, Ronald. Kouchibouguac: Removal, Resistance, and Remembrance at a Canadian National Park. Toronto: University of Toronto Press, 2016.

Schweizerischen Kompetenzzentrum für Menschenrechte. Die periodische Überprüfung der Menschenrechtslage der Schweiz (UPR): Eine Zwischenbilanz nach drei Zyklen. Bern, 2018.

Schweizerisches Kompetenzzentrum für Menschenrechte. Die Umsetzung internationaler Menschenrechtsempfehlungen im föderalistischen Staat: Perspektiven für das Follow-up zu den "Abschliessenden Bemerkungen" der UNO-Vertragsorgane in der Schweiz. Bern, 2012.

Schweizerischen Kompetenzzentrum für Menschenrechte. Umsetzung der Menschenrechte in der Schweiz. Schriftenreihe SKMR. Bern: Editions Weblaw, 2013-2014.

Singh, Mahendra P. "Federalism, Democracy and Human Rights: Some Reflections." Journal of the Indian Law Institute 47, no. 4 (2005): 429-46.

Spenlé, Christoph, and Jan Skalski. "Das Staatenberichtsverfahren vor dem UNOAusschuss gegen die Diskriminierung der Frau: Das unterschätzte Instrument: Zur Funktion und Struktur der UNO-Staatenberichtsverfahren und ihrer Bedeutung für die Schweiz," Jusletter, October 31, 2011, No. 51. 
Steytler, Nico. "The Constitutional Conversation Between the Federal Structure and a Bill of Rights." IFF Working Paper Online No. 2.

Watts, Ronald L. Comparing Federal Systems. 3rd ed. Montreal and Kingston: McGillQueen's University Press, 2008.

Weber, Florian. "Die Umsetzung völkerrechtlicher Verträge im Bundesstaat." In Föderalismus 2.o - Denkanstösse und Ausblicke, edited by Bernhard Waldmann, Peter Hänni and Eva Maria Belser, 221-43. Bern: Stämpfli, 2011.

Wildhaber, Luzius, Arnaldur Hjartarson, and Stephen Donnelly. "No Consensus on Consensus? : The Practice of the European Court of Human Rights." Human Rights Law Journal 33 (2013): 248-63.

Wolman, Andrew. "The Relationship Between National and Sub-national Human Rights Institutions in Federal States." The International Journal of Human Rights 17, no. 4 (2013): 445-462.

Wyttenbach, Judith. Umsetzung von Menschenrechtsübereinkommen in Bundesstaaten: Gleichzeitig ein Beitrag zur grundrechtlichen Ordnung im Föderalismus. BadenBaden, Zürich, St. Gallen: Nomos Dike, 2017.

Zlabinger, Stephan. "Schleierhafte Gesetzgebung? - Das St. Galler Gesichtsverhüllungsverbot unter dem Aspekt der Rechtsgleichheit in der Rechtsetzung." ZBl 119 (2018): 580-93. 